\title{
MENYAMBUT SEKOLAH RUMAH (HOMESCHOOLING) DALAM SISTEM PENDIDIKAN NASIONAL DI INDONESIA
}

\begin{abstract}
Harun Al Rasyid*
Abstract

Homeschooling practice in Indonesia has just started in 2006. There are many reasons and philosophies in the presence of home schooling, both internally such as family and students, and externally such as educational considerations. In at least, there are three types of homeschooling, they are: (1) homeschooling for pre-school children, (2) homeschooling as the substitution and complementation to formal school and (3) homeschooling as a sustainable education program. As a new category in the formal education practice in Indonesia, the presence of homeschooling should immediately be set up its connectivity model with national education system within its holistic view. It will need a comprehensively conceptual, theoretical, and philosophical consideration being the foundation of homeschooling practice so that homeschooling may run in the normative path of education. In the other hand, there is a necessity for supporting regulations, policies and action plan, which would guarantee the continuity and development of homeschooling in Indonesia. Therefore, homeschooling contributions within national education system may soon be used effectively in the efforts of promoting the intellectual life of the nation.
\end{abstract}

Key words: homeschooling, model homeschooling, national education system

\section{PENDAHULUAN}

Homeschooling atau yang diterjemahkan sebagai "sekolahrumah" menjadi sebuah isu yang sangat sensasional di dunia pendidikan Indonesia pada awal tahun 2006/2007. Isu itu terutama terjadi ketika pemikiran dan praktek sekolahrumah diakomodasi oleh jajaran Direktorat Pendidikan Kesetaraan Direktorat Jenderal Pendidikan Luar Sekolah/Pendidikan Nonformal dan Informal Departemen Pendidikan Nasional (Dit Pendidikan Kesetaraan Detjen PLS/PNFI Depdiknas). Cara mengakomodasinya adalah dengan mengembangkan prosedur operasi standar pengakuan (akreditasi) pengalaman belajar yang diperoleh melalui sekolah rumah sebagai pengalaman belajar pada program pendidikan kesetaraan. Melalui mekanisme recognition of prior learning, pengalaman belajar yang didapat (calon) peserta didik diakui (diakreditasi) dengan penghargaan tertentu. Berdasarkan harga penghargaan itu beban belajar mereka terkurangi karena telah memiliki pengalaman belajar pendahuluan itu. Jajaran Direktorat Pendidikan Anak Usia Dini (Dit. PAUD Ditjen PLS/PNFI) juga menggunakan sekolah rumah sebagai

* Kepala BPPLSP Regional IV Surabaya salah satu cara peluncuran (delivery system) bagi program pendidikan anak usia dini.

Sekolahrumah tengah berkembang menjadi sebuah kategori baru bagi sistem pendidikan nasional di Indonesia. Oleh karena itu tidak mengherankan bila kehadirannya, model peluncurannya, metode belajar, isi pembelajaran, evaluasi, dan cara pengakuan hasil belajar pada sekolah rumah masih belum tersusun secara baku. Namun demikian, di tengah kehausan masyarakat akan hadirnya model pendidikan nasional yang mampu mengemban misi pemerataan akses/ layanan dan peningkatan mutu dan relevansi, kehadiran sekolahrumah cukup memberikan janji dan potensi untuk ikut menyelesaikan masalah pendidikan yang tengah dihadapi bangsa Indonesia.

Agar model sekolahrumah mampu terhubung (to link atau connect to) dan berfungsi dalam keseluruhan sistem pendidikan nasional di Indonesia, masih membutuhkan kreasi-kreasi tentang tata laksana, manajerial, dan regulasi yang cerdas dari setiap pemangku pemikiran, kebijakan, dan penyelenggara pendidikan di Indonesia. Akan menjadi sebuah kehilangan dan kerugian besar, bila kemunculan sekolah rumah disikapi dengan pola ofensif dan represif dengan alasan tidak/belum ada undang-undang dan peraturan 
yang mampu mengaturnya. Oleh kerena itu upaya menerima dan menempatkan model sekolahrumah dalam sistem pendidikan nasional adalah sebuah kebutuhan dan keharusan.

\section{PEMBAHASAN}

\section{Kembali ke Keluarga}

Pendidikan adalah semua usaha yang dilakukan dengan sengaja untuk membantu individu atau masyarakat (community) meningkatkan derajat kesejahteraan dan martabat kemanusiaannya seoptimal mungkin seiring norma-norma yang dijunjung tinggi. Menurut teori tabularasa, manusia adalah kertas putih bersih, interaksi dengan lingkunganlah yang memberikan tulisan, lukisan, dan warna pada kertas itu. Tulisan, lukisan dan warna kependidikanlah yang diharapkan tercetak pada kertas itu. Menurut teori heriditas, manusia yang baru lahir telah membawa potensi bakat, minat, dan kemampuan masing-masing. Pada saatnya sesuai dengan tingkat pertumbuhan dan kematangannya, potensi bakat, minat, dan kemampuan itu akan aktual (nampak nyata) dengan sendirinya. Adapun teori konvergensi menggabungkan dua aliran itu dan perwujudan kemampuan manusia adalah hasil yang sinergis antara heriditas dan intervensi lingkungan. Interaksi dengan lingkungan pula yang dapat mewujudkan potensi-potensi yang masih bersifat laten menjadi menampak dan aktual. Intervensi pendidikan bertujuan membangkitkan dan mengembangkan potensi tersebut sehingga menjadi aktual secara optimal seiring dengan norma-norma yang berlaku.

Secara atropologis dan kesejarahan, aktivitas pendidikan yang dilakukan umat manusia adalah kegiatan kebudayaan untuk mewariskan dan mengembangkan pengetahuan, keterampilan, dan sikap khususnya dari generasi terdahulu kepada generasi yang kemudian. Konkretnya, pendidikan pada awal mulanya adalah upaya pewarisan pengetahuan, keterampilan, dan sikap dari orang tua kepada anakanak mereka. Pewarisan "budaya" itu tidak saja dimaknai sebagai dari orang tua biologis kepada anakanak mereka, melainkan adalah dari generasi yang lebih tua kepada generasi yang lebih muda.

Dalam bentuknya yang paling "indigeneous", pendidikan itu berkembang dalam masyarakat yang berakar pada tradisi dan agama. Dalam perkembangan selanjutnya, seirama dengan semakin besar tantangan dan tuntutan perubahan di masyarakat, maka pendidikan dilaksanakan dalam bentuk yang lebih sistematis, mulai dari pola menyerahkan anak-anak dari orang tua biologis kepada ahli tertentu untuk diajari kemampuan yang bersangkutan sampai dengan model kesekolahan (universitas) yang sangat spesialistis.
Dengan demikian kelembagaan pendidikan kesekolahan muncul seiring dengan kebutuhan masyarakat akan layanan pendidikan secara lebih sistematis, terfokus, dan terorganisasi. Sementara itu, pendidikan luar sekolah yang masih ada (di luar sistem persekolahan) juga terus berkembang seiring dengan kebutuhan belajar masyarakat dan seiring pula dengan keterbatasan kemampuan sekolah dalam melayani kebutuhan belajar masyarakat.

Selama ini di Indonesia kebanyakan orang tua memasukkan anak-anak ke lembaga pendidikan, baik formal maupun nonformal, agar anak mendapatkan stimulasi yang tepat. Akan tetapi, di sisi lain, banyak pula masyarakat yang tidak mampu memasukkan anak-anak usia dini mereka ke lembaga pendidikan karena keterbatasan ekonomi atau alasan lainnya. Hal yang juga menarik adalah bahwa pada saat ini mulai banyak orang tua merasa lembaga pendidikan yang ada tak lagi dapat memberikan pendidikan terbaik bagi anak-anaknya. Di lembaga pendidikan, kalau kita cermati, banyak anak yang menyukai saat pulang, bukan saat-saat berada di sekolah untuk memahami informasi yang disampaikan (Ahsin, 2007).

Sekolah tidak lagi menjadi wadah persiapan anak didik memasuki masyarakat dengan berbagai perlengkapan yang dibutuhkan, melainkan menjadi wadah mendidik anak dengan pandangan dunia sesuai kebutuhan pemilik modal dan penguasa. Dengan demikian kemampuan baca, tulis, dan hitung tidak lagi menjadi hal utama yang dituntut.

Yang penting anak dapat duduk manis di kelas dan bisa bergaul dengan baik dengan teman-temannya, anak yang demikian itu sudah bisa naik kelas dan lulus sekolah. Anak yang berkelakuan aktif atau selalu menerawang dan bosan dengan pekerjaan sekolah akan direkomendasikan untuk diperiksa dokter dan diberi obat penenang atau tidak diijinkan masuk sekolah selama waktu tertentu. Akibatnya, anak sangat tergantung pada tekanan kelompok sebaya atau lingkungannya. Keluarga bukan lagi menjadi tempat berteduh utama (Kho, 2007).

Dalam kajian sosiologi pendidikan di Indonesia, sering ditulis dan dibicarakan demikian penting, urgent, strategis dan sentral peran lembaga keluarga dalam triange/ pendidikan nasional Indonesia. Bahkan lembaga kajian pendidikan konvensional keluarga senantiasa disebut sebagai lembaga 
pendidikan yang pertama dan utama. Cakupan makna "pertama dan utama" tidak hanya dalam dimensi waktu atau kronologis proses terjadinya pendidikan, namun juga dalam dimensi tanggung jawab. Betapapun proses pendidikan telah diselenggarakan oleh berbagai lembaga pendidikan formal maupun nonformal, secara sosio-historis kehadiran lembaga-lembaga pendidikan profesional itu merupakan pengganti peran atas peran lembaga keluarga sebagai lembaga pendidikan yang utama tadi. Dengan demikian, jelas dapat dikatakan lembaga pendidikan profesional itu menerima mandat dari lembaga keluarga untuk menyelenggarakan pendidikan bagi para anggota keluarga.

Ada yang menyebut bahwa lembaga keluargalah yang sesungguhnya secara nyata merupakan lembaga pendidikan seumur hidup. Sejak dalam kandungan sampai menjelang masuk liang lahat, para anggota keluargalah yang bertanggung jawab membimbing menuju jalan yang lurus (normatif). Dalam ajaran agama Islam, bila kita menghadapi orang sakaratul maut, menjadi kewajiban para anggota keluarganyalah yang membimbing untuk melafalkan kalimat syahadat, dan ucapanucapan lain yang baik (kalimah toyibah).

Pada dasarnya, keluarga merupakan lembaga pendidikan yang paling alamiah. Disebut paling alamiah karena prosesnya tanpa didramatisasi atau didesain secara rumit sebagaimana yang terjadi pada lembaga pendidikan profesional. Materinya yang meliputi seluruh bidang kehidupan, metodenya lebih mendekati keadaan yang sesungguhnya (konkret) dan evaluasinya dilakukan secara langsung. Dalam keluarga juga tidak mungkin terdapat komersialisasi jasa pendidikan. Orangtua yang memberikan pendidikan dan fasilitas pendidikan tentulah tidak mengharapkan imbalan materi, selain karena didorong oleh kewajiban moral. Suasana demikianlah yang tidak dimiliki oleh lembaga pendidikan profesional.

Secara alamiah, pada keluargalah kepribadian dan kultur manusia dibentuk dan merupakan dasar bagi pengembangan kepribadian dan kultur-kultur lainnya. Tidaklah terlalu sulit untuk membuat contoh kasus atas pengaruh dominan proses pendidikan dalam keluarga dalam membentuk kepribadian seseorang. Akan tetapi keberadaan lembaga keluarga beserta fungsi-fungsi ideal yang disandangnya saat ini telah mengalami diferensiasi, atau setidak-tidaknya mengalami perubahan ke arah yang lebih sempit (berkurang).
Berbagai bentuk lembaga dalam kehidupan modern dinilai telah menjadi ancaman yang bisa membuat lembaga keluarga kehilangan arti (Republika, 16 Agustus 1993:12). Akibatnya orang tua mengalami defisit peran dalam mendidik putra-putrinya.

Gambaran penerapan pendidikan dalam keluarga yang semula lengkap dan sempurna dan kemudian tergerogoti oleh hal-hal yang dikemukakan di atas, menyebabkan muncullah berbagai ide tentang sekolah yang menyenangkan sekaligus mencerdaskan anak. Memunculkan berbagai sekolah alternatif yang salah satu tujuannya adalah mengembalikan fungsi keluarga sebagai institusi pendidikan. Sebagai contoh, muncul sekolah alam yang mengajak anak-anaknya belajar lebih banyak di alam, sehingga tidak terlalu banyak belajar di dalam ruangan yang serba kaku dan tertutup. Setelah itu, muncul sekolah alternatif lainnya yang membebaskan anak didiknya untuk belajar apa saja sesuai dengan minatnya. Di sekolah ini tidak ada kelas seperti halnya di sekolah formal. Guru hanya berfungsi membimbing dan mengarahkan minat anak-anak dalam mata pelajaran yang disukainya. Di samping itu juga masih banyak sekolah alternatif lain yang mempunyai metode pelajaran sendiri.

Dari berbagai alternatif sekolah itu muncullah homeschooling. Secara etimologis, homeschooling adalah sekolah yang diadakan di rumah, akan tetapi, secara hakiki, homeschooling adalah sebuah sekolah alternatif yang menempatkan anak-anak sebagai subyek dengan pendekatan pendidikan secara "at home". Dengan pendekatan at home inilah anak-anak merasa nyaman belajar karena mereka bisa belajar apa saja sesuai dengan keinginannya, kapan saja dan di mana saja seperti ia tengah belajar di rumahnya. Jadi, meskipun disebut homeschooling, tidak berarti anak akan terus menerus belajar di rumah, tetapi anak-anak bisa belajar di mana saja dan kapan saja asal situasi dan kondisinya benar-benar nyaman seperti at home, sehingga jam pelajaran fleksibel, mulai dari bangun tidur sampai berangkat tidur kembali (Mulyadi, 2006).

\section{Subtansi dan Jenis}

Homeschooling juga disebut sebagai home education atau home school adalah pendidikan untuk anak-anak di rumah bukan di sekolah umum. Homeshooling di negara-negara yang berbahasa nasional Bahasa Inggris, merupakan pilihan bagi orang 
tua yang menginginkan pendidikan yang berkualitas bagi anak-anaknya atau lingkungan sosial yang baik, yang tidak disediakan oleh sekolah. Pada awal tahun 1977, homeschooling berada di bawah supervisi correspondence school atau umbrella schools. Kurikulum yang digunakan pada saat itu disebut dengan unschooling, yang diberi nama oleh John Holt.

Homeschooling sebenarnya dilaksanakan jauh sebelum pendidikan modern muncul. Sebelum abad ke-18 umumnya anak-anak dididik oleh keluarganya sendiri atau memanggil guru privat ke rumah. George Washington, Abraham Lincoln, Tomas Alva Edison, dan
Benjamin Franklin adalah contoh orang-orang awam yang menjalani pendidikan di rumah atau belajar sendiri tanpa guru. Pendidikan massal dimulai sejak berkembangnya psikologi dan filsafat modern, terutama sejak munculnya filsafat pragmatisme dari John Dewey dan pandangan Unitarian dari Horace Mann, yakni mulai tahun 1860 (Kho, 2007).

Beberapa tahun kemudian, terjadi perkembangan yang sangat pesat dalam pendidikan yang menggunakan homeschooling di luar negeri. Sensus yang dilakukan di Amerika pada tahun 1999 memberikan data sebagai berikut.

Tabel 2. Alasan Penyelenggaraan Homeschooling di USA, 1999

\begin{tabular}{|l|c||c|c|}
\hline \multicolumn{1}{|c|}{ Reason for homeschooling } & $\begin{array}{c}\text { Number of } \\
\text { homeschooled students }\end{array}$ & Percent & s.e. \\
\hline \hline Can give child better education at home & 415,000 & 48.9 & 3.79 \\
\hline Religious reasons & 327,000 & 38.4 & 4.44 \\
\hline \hline Poor learning environment at school & 218,000 & 25.6 & 3.44 \\
\hline Family reasons & 143,000 & 16.8 & 2.79 \\
\hline \hline To develop character/morality & 128,000 & 15.1 & 3.39 \\
\hline \hline Object to what school teaches & 103,000 & 12.1 & 2.11 \\
\hline School does not challenge child & 98,000 & 11.6 & 2.39 \\
\hline \hline Other problems with available schools & 76,000 & 9.0 & 2.40 \\
\hline \hline Child has special needs/disability & 69,000 & 8.2 & 1.89 \\
\hline Transportation/convenience & 23,000 & 2.7 & 1.48 \\
\hline \hline Child not old enough to enter school & 15,000 & 1.8 & 1.13 \\
\hline \hline Want private school but cannot afford it & 15,000 & 1.7 & 0.77 \\
\hline \hline Parent's career & 12,000 & 1.5 & 0.80 \\
\hline \hline Could not get into desired school & 12,000 & 1.5 & 0.99 \\
\hline \hline Other reasons ${ }^{*}$ & 189,000 & \\
\hline \hline Sumber : National Center for Educalion & & & \\
\hline
\end{tabular}

Sumber : National Center for Education Statistic (NCES)

Sebuah hasil survei di AS (1999) menemukan beberapa kondisi yang menjadi alasan orang tua memilih homeschooling bagi anaknya adalah sebagai berikut.

a. $85 \%$ orang tua memilih homeschooling karena alasan lingkungan sosial seperti rasa aman, narkoba, bullying, dan adanya tekanan dari teman sebaya.

b. $72 \%$ orang tua memilih homeschooling karena alasan ingin mendidik anak sesuai agama kepercayaan yang dianut.

c. $70 \%$ orang tua memilih homeschooling karena alasan kesehatan fisik atau mental anaknya.

d. $7 \%$ orang tua memilih homeschooling karena alasan kebutuhan khusus anak

e. $9 \%$ orang tua memilih homeschooling karena alasan ingin bersikap fleksibel dalam pemberian pendidikan bagi anak.

Hal lain yang juga menjadi alasan orang tua memilih homeschooling bagi anaknya adalah sebagai berikut.

a. Orang tua sering berpindah tempat tugas. b. Anak berkarir sebagai artis.

c. Cara mengajar guru tidak sesuai bagi anak.

d. Pelajaran sekolah kurang menarik minat anak. Homeschooling dipilih sebagai alternatif pendidikan karena dinilai memiliki kelebihan-kelebihan sebagai berikut.

a. Efisien. Homeschooling jauh lebih efektif karena anak bisa memiliki waktu lebih banyak untuk belajar dan mengerjakan sesuatu dibandingkan di sekolah. Dengan belajar di rumah anak tak perlu lagi menghabiskan waktu yang tak efektif untuk perjalanan menuju ke dan kembali dari sekolah dan melakukan persiapan-persiapan rutin lainnya. Dengan ekstra waktu, anak memiliki lebih banyak kesempatan untuk mengekplorasi hal-hal edukatif lain yang sesuai dengan minatnya.

b. Mencegah pelajaran berulang. Dalam kurikulum sekolah konvensional, seringkali anak-anak dihadapkan pada bahan pelajaran yang disampaikan berulang-ulang dalam waktu cukup lama. 
c. Kesempatan memperoleh perhatian yang lebih personal. Dengan homeschooling orang tua dapat mudah memberikan bantuan lebih personal pada anak-anaknya, misalnya dengan memberikan perhatian lebih pada mata pelajaran yang masih sulit untuk dikuasai dan mengurangi waktu untuk mempelajari hal-hal yang sudah dikuasai dengan baik oleh anak. Walaupun memiliki banyak kelebihan, lingkungan homeschooling yang mengambil tempat belajar di rumah sering menimbulkan kekhawatiran orang tua pada kemampuan anak bersosialisasi. Mengenai hal ini, sebenarnya anak tidak hanya bisa bersosialisasi di sekolah. Ada kesempatan lain bagi anak untuk berinteraksi dan belajar dari lingkungan masyarakat dengan berbagai latar belakang usia, gender, dan minat. Selain itu, anak juga mempunyai banyak waktu luang untuk ikut serta dalam aktivitas dan berinteraksi di luar rumah dengan mengikuti kursus musik, ikut klub olahraga, aktif di kegiatan ibadah, dan lain sebagainya. Dari penelitian terbukti bahwa anak dengan program homeschooling lebih percaya diri dan kurang bergantung pada orang lain dibandingkan dengan anak-anak yang mengenyam pendidikan di sekolah umum.

Di samping itu, homeschooling dipilih karena adanya alasan bahwa kecerdasan majemuk anak dapat dioptimalkan. Menurut Rahman dalam "Mengoptimalkan Kecerdasan Anak (2005:8)", kecerdasan adalah pemahaman dan kesadaran anak terhadap apa yang dialaminya. Selanjutnya dikatakan pula bahwa pemahaman akan berbuah pengetahuan, sedangkan pengetahuan masih harus dibandingkan dengan pengalaman dan fakta sehari-hari. Kemampuan dalam membandingkan pengetahuan dengan pengalaman inilah yang disebut dengan kecerdasan. Kecerdasan sebenarnya telah ada dan mengakar dalam saraf manusia, terutama dalam otak yang merupakan pusat seluruh aktivitas manusia (Surya, 2007).

Homeschooling mulai muncul di Indonesia terutama didasari oleh konsep bahwa memelihara kemerdekaan anak dan mengasah mereka berjiwa mandiri merupakan sebuah keharusan dan ini merupakan tantangan tersulit seorang pendidik. Hampir seluruh anak Indonesia tumbuh dengan rutinitas tanpa daya kejut dengan menu wajib berupa tumpukan tugas bernama pekerjaan rumah, dilengkapi ketentuan seragam, buku paket wajib, dan lulus ujian nasional.

Bagi anak, belajar sesungguhnya didorong oleh motif rasa ingin tahu. Peran penting pendidik adalah menemukan berbagai cara untuk menumbuhkan keingintahuan anak dan mengarahkannya dengan cara yang paling mereka harapkan, dan paling mereka minati. Jika anak diberi rasa aman, dihindarkan dari celaan dan cemoohan, berani berekspresi dan bereksplorasi secara leluasa, ia akan tumbuh dengan penuh rasa percaya diri dan berkembang menjadi dirinya sendiri.

Cengkeraman birokrasi dan favoritisasi sekolahlah yang menyulitkan penyelenggaraan pendidikan formal di negara kita untuk menerapkan falsafah pendidikan dalam konteks pencerahan dan pembebasan. Oleh karena itu, tidak seharusnya apabila praktek-praktek kelas yang mengekang hak anak untuk mengembangkan diri juga dilanggengkan dalam penyelenggaraan pendidikan, seperti "sekolahrumah tunggal" dilaksanakan sendiri oleh sebuah keluarga untuk putra putrinya.

Tidak banyak orang yang memiliki falsafah pendidikan yang khas untuk melakukan usaha sadar dan terencana sesuai amanat Undang-undang Sistem Pendidikan Nasional, pasal 1 ayat 1 , yang menyebutkan bahwa pendidikan adalah usaha sadar dan terencana untuk mewujudkan suasana belajar dan proses pembelajaran agar peserta didik secara aktif mengembangkan potensi dirinya untuk memiliki kekuatan spiritual keagamaan, pengendalian diri, kepribadian, kecerdasan, akhlak mulia, serta keterampilan yang diperlukan dirinya, masyarakat, bangsa dan negara. Dalam konteks ini, ditemukan alasan positif untuk meninggalkan sekolah. Belajar di rumah bisa membantu penyelenggara "sekolah rumah tunggal" untuk merumuskan falsafah khas mereka (Lane, 2000).

Orang tua adalah pendidik terbaik. Anak tak akan membiarkan orang tua sendirian dalam menyelenggarakan sekolah rumah, agar anak terus tumbuh dengan pendidikan anak merdeka. Keyakinan ini sangat bermakna dalam proses tumbuh bersama dengan kemerdekaan untuk mengembangkan bakatbakat luhur kemanusiaan tanpa paksaan dari pihak mana pun, demikian yang disampaikan oleh banyak penyelenggara homeschooling.

Tantangan tersulit bagi keluarga yang menyelenggarakan sekolahrumah adalah menjaga agar falsafah khas dapat diwujudkan dalam suasana belajar dan proses pembelajaran berdasarkan pengalaman yang tumbuh subur dan kreatif dalam menata ulang pengalaman berikutnya, seperti yang dirumuskan John Dewey (Dewey, 2004). Pengetahuan tentang perkembangan anak harus terus diasah untuk mewujudkannya.

Homeschooling merupakan sebuah model pendidikan yang memberikan kelenturan atau 
fleksibitas dalam penyelenggaraannya, sehingga anakanak dapat belajar dalam situasi yang menyenangkan dan nyaman. Feeling at home, demikian konsep yang ingin dibangun dalam penyelenggaraan homeschooling, sehingga kenyamanan, kebutuhan dan minat anak menjadi fokus perhatian utama.

Homeschooling sebagaimana bentuk-bentuk pendidikan alternatif lainnya, memiliki beberapa jenis model. Beberapa jenis model homeschooling ini juga terbagi atas dua karakteristik. Karakteristik yang pertama adalah berdasarkan pada cara penyelenggaraannya, yang dapat diuraikan sebagai berikut.

1. Model sekolah di rumah (school-at-home).

Model ini merupakan metode yang paling mahal dan mempunyai tingkat kegagalan yang paling tinggi. Peserta program membeli suatu set kurikulum dengan buku-buku, jadwal belajar, tingkatan kelas beserta cara evaluasinya. Mereka juga akan berhubungan dengan penyedia kurikulum untuk menyerahkan tugastugas yang dimuat untuk dinilai dan dievaluasi. Peserta yang memakai model ini juga dapat membuat rencana dan materi pembelajaran sendiri. Keuntungan model ini adalah, peserta tahu dengan pasti apa yang akan diajarkan dan kapan mengajarkannya. Sebaliknya kerugiannya adalah model ini memerlukan pekerjaan dan perhatian yang lebih banyak dari orangtua/ pengajar. Selain itu, besar kemungkinan pelajaran yang diberikan tidak terlalu menyenangkan bagi anak-anak.

2. Model unit pengajaran (unit studies). Model ini memakai minat masing-masing anak dalam suatu subyek dan kemudian menyatukannya dalam bidang-bidang lain seperti matematika, bahasa pengetahuan umum, sejarah, dan sebagainya. Misalnya, bila anak berminat mempelajari negara Mesir, maka ia akan belajar mengenai sejarah Mesir, membaca buku tentang Mesir, menulis karangan tentang Mesir, membuat art project tentang piramida sekaligus meneliti benda-benda kuno di Mesir dan sebagainya. Model ini dapat menjadi metode pembelajaran yang santai sambil bereksplorasi berdasarkan minat melalui suatu obyek atau pendekatan alamiah yang terdapat dalam paket unit pengajaran. Keuntungan model ini terletak pada minat anak. Pada kenyataannya, anak akan belajar lebih baik bila ia memiliki minat pada topik itu. Kekurangannya, menurut Utami, kadang-kadang orangtua terlalu bersemangat dan berlebihan dalam membahas subyek ini. Akibatnya, anak menjadi takut membicarakan subyek lain yang diminatinya.

3. Model ekletik merupakan metode homeschooling yang santai dan paling banyak digunakan. Pada dasarnya model ini menggunakan sedikit perlengkapan juga bahasa dan pendekatan yang bebas. Dengan metode ini orang tua dapat merasakan subyek-subyek apa yang menurutnya paling penting secara keseluruhan. Peserta dapat memilih buku-buku membuat karya wisata dan ikut serta dalam kelas-kelas yang cocok dengan keperluan dan minatnya.

4. Model unschooling dikenal sebagai metode pembelajaran alami yang praktiknya dilakukan berdasarkan minat dan keingintahuan anak. Peserta belajar dari pengalaman seharihari dan tidak menggunakan jadwal sekolah atau kurikulum formal. Dengan demikian, anakanak mempunyai cukup waktu dan kemampuan dalam meneliti sehingga mereka akan menjadi ahli dalam bidang yang ia minati. Namun model ini juga memiliki kerugian karena sulit bagi mereka dalam mengikuti penyetaraan tingkatan atau kelas apabila ingin memasuki kembali sistem sekolah umum.

Karakteristik kedua adalah berdasarkan pada kelompok belajarnya. Berdasarkan pada karakteristik ini, model homeschooling yang diselenggarakan antara lain berbentuk sebagai berikut.

1. Sekolahrumah tunggal, merupakan layanan pendidikan yang dilakukan oleh orang tua atau wali terhadap seorang anak atau lebih terutama di rumahnya sendiri, atau di tempat-tempat lain yang menyenangkan bagi peserta didik.

2. Sekolahrumah majemuk merupakan layanan pendidikan yang dilakukan oleh para orang tua atau wali terhadap anak-anak dari suatu lingkungan yang tidak selalu bertalian dalam keluarga, yang diselenggarakan di beberapa rumah atau di tempat atau fasilitas pendidikan yang ditentukan oleh suatu komunitas pendidikan yang dibentuk atau dikelola 
secara lebih teratur dan terstruktur (Direktorat Pendidikan Kesetaraan, 2006).

\section{Di mana ditempatkan}

Sistem pendidikan nasional di Indonesia belum mengatur keberadaan dan mekanisme sekolahrumah, baik yang diatur dalam peraturan dan perundangundangan maupun dalam kebijakan Departemen Pendidikan Nasional. Oleh karena itu perlu segera ada keputusan, kebijakan, dan regulasi tentang sekolah rumah yang mampu menghubungkan praktek pendidikan sekolah rumah dengan sistem pendidikan nasional. Ada satu hal yang perlu disepakati bahwa satuan penyelenggaraan sekolahrumah ditinjau dari status kelembagaannya adalah informal. Apabila mampu dilembagakan menjadi satuan pendidikan nonformal masalah kredensial ini bisa menjadi isu (dikeluarkan) oleh satuan sekolahrumah yang bersangkutan. Tentu pemikiran ini masih belum bersifat final.

Untuk tingkat pendidikan prasekolah, koneksitas praktek sekolah dengan model pendidikan prasekolah lainnya, seperti Taman Kanak-kanak, Kelompok Bermain, Bustanul Athfal, Madrasah Diniyah, dan sebagainya; tidaklah mengalami banyak hambatan karena pendidikan prasekolah pada dasarnya adalah perpanjangan dari pendidikan keluarga. Pada sisi lain, pendidikan prasekolah tidak menjadi prasyarat bagi tingkat pendidikan dasar (SD/MI). Oleh karena itu koneksitas sekolahrumah tingkat prasekolah sekolah tidak banyak membutuhkan penatalaksanaan yang rumit. Masalah penatalaksanaan timbul bila peserta didik ingin mendapatkan kredensial (surat keterangan, sertifikat, atau ijazah) dari lembaga pendidikan resmi (nonformal dan formal). Karena sifat sekolahrumah pada tingkat pendidikan prasekolah adalah informal maka bisa jadi untuk ihwal kredensial, kelembagaan sekolah rumah perlu berafiliasi kepada satuan pendidikan prasekolah formal yang ada di sekitarnya atau sama sekali tidak perlu mementingkan kredensial.
Pada tingkat yang lebih tinggi, praktek sekolahrumah untuk kompetensi pendidikan dasar dan menengah dapat dikaitkan (koneksitas) dengan sistem pendidikan kesetaraan sebagaimana yang dikembangkan oleh Dit Pendidikan Kesetaraan Detjen PLS/PNFI Depdiknas). Cara mengakomodasinya adalah dengan mengembangkan prosedur operasi standar pengakuan (akreditasi) pengalaman belajar yang diperoleh melalui sekolah rumah sebagai pengalaman belajar pada program pendidikan kesetaraan. Melalui mekanisme recognition of prior learning, pengalaman belajar yang didapat (calon) peserta didik diakui (diakreditasi) dengan penghargaan tertentu. Peraturan Menteri pendidikan Nasional (Permendiknas) Nomor 16 tahun 2007 tentang Standar Isi Pendidikan Kesetaraan dapat digunakan sebagai acuan dalam mengukur kemampuan belajar terdahulu untuk diakui sebagai sebuah satuan kredit kompetensi pada sistem pendidikan kesetaraan.

Sedangkan untuk jenis praktek sekolahrumah yang berkarakter sebagai "pendidikan jarak jauh" dan "kumpul kredit" sebagai salah satu bentuk praktik pendidikan berkelanjutan (continuing education) dengan berbagai muatan isinya, koneksitasnya dengan sistem pendidikan nasional dapat dilakukan melalui mekanisme akreditasi dan sertifikasi yang dilakukan oleh lembaga/ asosiasi profesi sesuai dengan jenis vokasi yang dipelajari. Dalam hal ini peranan Badan Standar Nasional Pendidikan (BSNP) dan Badan Nasional Standarisasi Profesi (BNSP) dengan Lembaga Standarisasi Profesi (LSP)-nya sangat dibutuhkan. Sebagaimana bisa dilacak melalui situs-situs tentang homeschooling di dunia maya (internet), banyak sekali ditawarkan bentuk-bentuk pendidikan jarak jauh berbasis teknologi informasi. Demikian juga berbagai tawaan pendidikan jarak jauh melalui korespondensi. Hasil-hasil belajar dan uji kompetensi dari program ini perlu dilakukan melalui lembaga LSP apabila peserta didik membutuhkan sertifikasi vokasional yang telah dipelajari.

\section{KESIMPULAN}

Berbagai pemikiran menghubungkan (koneksitas) model sekolah rumah dalam sistem pendidikan nasional ini perlu jabaran operasional lebih lanjut, baik pada tataran aturan perundangan, kebijakan, maupun pada tataran tata kelola. Oleh karena itu kepedulian dan campur tangan berbagai pihak, khususnya lembaga pengembangan pendidikan sangat dibutuhkan. Kehadiran sekolahrumah sebagai kategori baru dalam sistem pendidikan nasional tidak bisa diabaikan. Apabila diabaikan akan menjadi kerugian besar bagi bangsa Indonesia. Penerapan konsep dan filosofi homeschooling pada dasarnya sebagian besar diarahkan untuk mengembalikan hakekat peranan keluarga pada pendidikan anak yang tidak pernah tergantikan, sehingga tanggung jawab akan pendidikan anak tidak semata-mata diserahkan kepada sekolah yang bersifat formal. 
Ahsin, M.I. (2007). Dunia tanpa sekolah. Bandung: Mizan.

Bahruddin, A. (2007). Pendidikan alternatif Qaryah Thayyibah. LKIS. Jakarta

Direktorat Pendidikan Kesetaraan. (2006). Komunitas sekolah rumah sebagai satuan pendidikan kesetaraan. Jakarta: Direktorat Jenderal Pendidikan Luar Sekolah, Depdiknas.

Direktorat Pendidikan Kesetaraan. (2006). Pendidikan kesetaraan mencerahkan anak bangsa. Jakarta: Direktorat Jenderal Pendidikan Luar Sekolah, Depdiknas.
Mulyadi, S. (2006). Homeschooling, pendidikan alternatif masa depan. Makalah. Jakarta

Mulyadi, S. (2007). Homeschooling keluarga Kak Seto. Bandung: Kaifa

(2002) Undang-Undang Dasar Republik Indonesia Tahun 1945 (Perubahan Pertama, Kedua, Ketiga, dan Keempat).

(2003) Undang-Undang Republik Indonesia Nomor 20 Tahun 2003 tentang Sistem Pendidikan Nasional. Jakarta: Departemen Pendidikan Nasional. 